Драгана Радојчић

Универзитет у Београду

Филолошки факултет

Катедра за славистику

draganaradojcic16@gmail.com
УДК 811.161.1'27

https://doi.org/10.18485/slavistika.2021.25.2.17

Стручни рад

примљено 28.7.2021.

прихваћено за штампу 6.10.2021.

\title{
ЛИНГВИСТИЧКЕ И ЛИНГВОКУЛТУРОЛОШКЕ КОМПЕТЕНЦИЈЕ ИЗАСЛАНИКА ОДБРАНЕ У РУСОФОНОЈ СРЕДИНИ
}

Стицање говорне, комуникативне, лингвистичке и културолошке компетенције важан је елемент образовног циља наставе страног језика, што подразумева способност језичке реализације у говору, одговарајућег степена комуницирања, као и овладавање знањима о језику са аспекта културних и духовних специфичности социокултурне заједнице конкретног језичког подручја.Када је реч о знању страног језика официра на дужностима изасланика и помоћника изасланика одбране у иностранству, треба обратити пажњу и на компетенцију која се односи на познавање војне терминологије. Елементи невербалне комуникације такође доприносе упознавању са моделима и стандардима понашања у свакодневним ситуацијама, као и интеркултурну комуникацију.

Познавање страног (руског) језика изасланика одбране у русофоној средини подразумева не само напредни ниво језичке, комуникативне и лингвокултуролошке компетенције, већ и високи степен познавања језика војне струке, што омогућава квалитетну професионалну комуникацију.

Под лингвистичком компетенцијом у нашем раду подразумевамо говорну, комуникативну, терминолошку и преводилачку компетенцију изасланика одбране. Одабир дидактичког језичког материјала треба да одговара циљу наставе, тј. усвајању поменутих знања и вештина.

Паралелно са високим степеном знања званичног (службеног) језика земље пријема (на свим језичким нивоима), за изасланика одбране пожељно је и познавање енглеског језика на нивоу елементарне комуникације, као и основних термина из професионалне сфере на овом језику.

Кључне речи: изасланик одбране, страни (руски) језик, култура, лингвистичка компетенција, лингвокултуролошка компетенција, социокултурна заједница, екстралингвистички садржај, терминологија, језик војне струке.

Gaining spoken, communicative, linguistic and cultural competences is an important part of the foreign language teaching educational goal. This presumes one's ability of language realization in speaking, communication at an adequate level, as well as mastering language knowledge from the aspect of cultural and spiritual specificities of a sociocultural environment in a particular language area.

When it comes to the foreign language knowledge of the Defense Attaché and Assistant Defense Attaché, attention should also be paid to the competence in terms of military terminology knowledge. The elements of nonverbal communication also contribute to introducing models and standards of behavior in everyday situations, as well as to intercultural communication.

A good command of a foreign (Russian) language of a Defense Attaché in the Russian environment presumes not only an advanced level of linguistic, communicative and linguocultural competences, but also a high level of the language for specific purposes (Military Russian), which enables high quality and professional communication.

In this paper, we presume the spoken, interactive, terminological and translational competence of the Defense Attaché as their linguistic competences. Therefore, the choice of didactic material should correspond to the aim of teaching, i.e. to the acquisition of the aforementioned knowledge and skills. 
Apart from a high level of language knowledge of the host country (on all levels according to the CEFR), it is recommended for a Defense Attaché to know English at the level of basic communication, as well as to master the basic terminology in professional sphere in this language.

Keywords: Defense Attaché, foreign (Russian) language, culture, linguistic competence, linguocultural competence, sociocultural environment, extralinguistic content, terminology, military language.

Данашњи свет тешко је замислити без мултикултуралности и мултилингвалности, стога високи ниво знања страних језика доприноси остваривању успешне комуникације са носиоцима различитих језика у оквиру шире социокултурне заједнице. Како би се таква комуникација остварила, неизоставни елемент образовног циља наставе страног језика јесте стицање говорне, комуникативне, језичке и културолошке компетенције, посебно када је реч о међукултурној професионалној комуникацији која налаже познавање културе, модела и стандарда понашања изворних говорника језика који се учи.

На прелазу из XX у XXI век у комуникативној лингвистици појављују се термини комуникативна личност и комуникативно понашање. Према Стерњиновој дефиницији комуникативна личност се одликује извесним типским комуникативним понашањем, док је комуникативно понашање нормирано и усклађено са традицијама комуникације у конкретној заједници: «Таким образом, коммуникативная личность - это личность, которая характеризуется некоторым типовым коммуникативным поведением. Коммуникативное поведение - это поведение (вербальное и сопровождающее его невербальное) народа, личности или группы лиц в процессе общения, регулируемое нормами и традициями общения данного социума» (Стернин 2007: 8). ${ }^{1}$

Како наводи Кончаревић, комуникативна личност не обухвата само лингвистичке, већ и комуникативне параметре: „Појам комуникативне личности шири је од појма језичке личности, будући да, поред уско лингвистичких, укључује и комуникативне параметре" (Кончаревић 2010: 267).

Појам професионална комуникативна личност подразумева комуникативно понашање представника различитих професија. Како наводи Стерњин, професионално понашање ствара професионалну комуникативну личност која се може реализовати као индивидуална или колективна, тј. «коммуникативная индивидуальность некоторого социума» (Стернин 2007: 4, 176-177).

Како наводи Пасов, садржај комуникације произилази из садржаја мишљења, а свест одражава објективну реалност у процесу људске делатности (Пассов 1989: 14).

У литератури на руском језику проучаване су комуникативне личности лекара -Дедова 2000., доктора психотерапеута - Багдасарян 2005, филолога - Саломатина 2007, радио и телевизијских водитеља - Беспамятнова 2007, Мокичева 2005, државних службеника - Панова 2004, као и војних лица Багрянская 2004. године (Кончаревић 2010: 268; Стернин 2007: 13).

\footnotetext{
1 „На тај начин комуникативна личност је она која се одликује извесним типским комуникативним понашањем. Комуникативно понашање је понашање (вербално и пратеће невербално) народа, личности или групе лица у процесу комуникације, које је регулисано нормама и традицијама комуникације у датом социјуму” (Стернин 2007: 8). (прев. Д. Р.)
} 
Увидом у доступни део литературе на руском и српском језику нисмо се сусрели са лингвистичким и лингвокултуролошким проучавањима посвећеним представницима војне дипломатије као специфичне професије у оквиру војне струке.

Када је реч о лингвистичком аспекту различитих професија, 70-их година прошлог века уведен је појам језик за специјалне/специифичне ичиљеве (ЯСЦ язык для специальных изелей), односно језик струке или језик у функиији струке, као подсистем језика опште комуникације. Његова функција састоји се у ефикаснијој професионалној комуникацији између представника конкретних струка. Како наводи Сорокина, језик струке је систем са више нивоа и на сваком од њих одликује се специфичностима одређене професије: «В настоящее время язык для специальных изелей рассматривается как многоуровневая система, имеющая на каждом уровне свои отличительные черты, определяемые спецификой профессиональной отрасли» (Сорокина 2016: 169). ${ }^{2}$ Језик струке реализује се како у писменом, тако и у усменом облику.

У овом раду не усмеравамо пажњу на комуникативно понашање официра као личности условљених својом професијом (нпр. одлучност и одсуство емоционалности у говору, категоричност, гласан говор), нити на њихове типичне особине или представе о њима, већ на лингвистичке и лингвокултуролошке компетенције изасланика одбране, односно комуникативне компетенције које им омогућавају комуникацију и ефикасну примену језичких знања у ситуацијама које подразумева ова професија.

С обзиром на то да су култура и језик повезани зато што се језик не може одвојити од културе етноса, у наставу руског језика струке (за будуће изасланике одбране и њихове помоћнике) треба укључити и лингвокултуролошки садржај који носи информације о одређеном језичком подручју на лексичком, граматичком и синтаксичком нивоу, имајући у виду да кумулативна функција језика омогућава „складиштење”, тј. акумулирање духовне баштине народа. Језик спаја генерације преношењем колективног искуства, због чега „kultura svake zajednice uveliko počiva na ovoj funkciji jezika“ (Bugarski 2003: 39).

Основни образовни циљ наставе страних језика на нивоу B2/C1 Заједничког европског референтног оквира за учење, наставу и евалуацију страних језика усмерен је и на стицање културолошких знања. Он подразумева савладавање четири говорне вештине (слушање, читање, говор, писање), као и стицање способности комуникације на страном језику у датој говорној средини, што је често повезано са знањима из општекултурног домена. У најкраћим цртама, ниво В2 налаже разумевање комплекснијих текстова конкретног или апстрактног садржаја, укључујући и стручну лексику одређеног професионалног терминосистема, аргументовање сопствених ставова, неометану комуникацију са изворним говорницима, док се на нивоу С1 очекује још виши ниво овладавања језичким вештинама, функционалним стиловима, комуникативна компетенција у различитим колоквијалним, професионалним и академским контекстима.

\footnotetext{
${ }^{2}$ „Данас се језик за специјалне цииљеве посматра као систем са више нивоа, који на сваком од њих има своје посебне карактеристике, одређене специфичностима конкретне професије" (Сорокина 2016: 169). (прев. Д. Р.)
} 
Узимајући у обзир поменуте чињенице, дидактички језички материјал намењен полазницима курсева В2 и С1 нивоа треба да омогући повезивање језичког материјала са различитим аспектима културе, што подразумева усвајање знања из националне традиције, познавање обичаја и историје конкретног језичког подручја, као и упознавање са чињеницама културе на матерњем језику. Полазнике треба упознавати и са језичким изразом за социокултурне чињенице које су саставни део свакодневног савременог живота (Кончаревић 2004: 184, 186). Зато је потребно одабрати текстове са конотативним лексичким јединицама и лексиком фона (позадине) са израженом културном компонентом (руски: фоновая лексика), која подразумева језичка средства са допунским садржајем и стилском разноликошћу, а односи се на реалије у страном и матерњем језику. То су „речи које на појмовном плану имају еквиваленте у другом језику, али се у неким семантичким одликама не подударају" (Кончаревић 2004: 189). Тако српска лексема чај и руска чай према лексици фона нису потпуни еквиваленти, јер се код Руса она асоцира са ритуалом испијања чаја, слично као што Срби имају „асоцијативну позадину ове речи” у вези са испијањем кафе (Кончаревић 2004: 190). Недовољно познавање конотације може довести до проблема у комуникацији због неправилне употребе исказа у конкретном страном језику. Информативни текстови из области географије, економије, политике, геополитике и сл. такође су корисни, јер садрже лексику свакодневне комуникације, у којој се уочавају и карактеристике менталитета савремених изворних носилаца страног језика. Стицање оваквих знања подразумева информације о територији на којој се говори конкретни страни језик, податке о националном, конфесионалном и социјалном саставу становништва, о привреди, економији, култури, друштвеном уређењу, историји, о климатским специфичностима, временским зонама и сл.

Семантизацију овакве лексике најбоље је вршити у оквиру тематских група речи, док се проналажењем преводних еквивалената систематизују знања везана за сопствену социокултурну реалност.

Добро познавање граматичких категорија такође има веома важну, фундаменталну улогу у стицању ове компетенције.

Поред наведеног, у наставни материјал треба уврстити и нееквивалентну (беспреводну) лексику, која најчешће означава појмове типичне за конкретну нацију, због чега лексичке јединице овога типа нису саставни део лексичког фонда матерњег језика. Из тог разлога оне се најчешће преузимају из страног језика (уз одређене степене адаптације), или се описно преводе, нпр. самова́р (српски: самовар); матрёика (српски: матрјошка, бабушка); кефиір (српски: кефир); борщ, щии (српски: боршч, шчи); затим деадјективни супстантиви попут парикмахерская (српски: фризерски салон), гостиная (српски: дневна соба), столовая (српски: менза, кантина) и сл. Такође, треба скренути пажњу на међујезичке хомониме у основним терминима војне струке, као што су: пушка (српски: тоn), заражение (српски: контаминација), поражение (српски: уништавағе), као и на унутарјезичке парониме, као што су у руском језику заряжение и заражение (у српском језику нису пароними: пуњење и контаминачија).

Када је реч о вербалном и невербалном комуникативном понашању, у наставку би требало укључити и основне информације о стандардима карактери- 
стичним за земљу чији се језик учи. У случају најчешћих невербалних средстава комуникације (гестови, мимика, позе, покрети), они су условљени комуникативном ситуацијом, што олакшава споразумевање при визуелном и аудитивном контакту саговорника. Када говоримо о функцији ситуације у процесу учења страног језика, Пасов закључује да „ситуација као методичка категорија представља јединицу организовања процеса наставе страног језика” (Пассов 1989: 50). За руско говорно подручје занимљиво је поменути да бројање на прсте почиње у смеру од малог прста према палцу, савијањем сваког прста кажипрстом друге руке, а у случају када се гестом жели показати да је неко у алкохолисаном стању, истовремено се кажипрстом и средњим прстом куцне по врату (приближно у нивоу крагне). С тим у вези, наставни материјал треба да садржи и ситуативне фотографије, видео и аудио материјале, а треба користити и могућности савремених електронских средстава.

За професију официра релевантно је и упознавање са карактеристичним елементима живота и рада колега официра на конкретном иностраном културнојезичком простору. Текстови са војном тематиком од огромне су важности јер дају информације о животу и раду ове професионалне структуре, као и о језичким специфичностима не само војне терминологије, већ и војног жаргона. Филмови са војном и ратном тематиком, као и адекватни музички садржаји (текстови песама, познатији маршеви) такође доприносе стицању лингвокултуролошке компетенције код полазника.

У процесу учења руског и осталих словенских језика важно је водити рачуна о улози позитивног трансфера (фацилитације), као и негативног трансфера (интерференције). Ово се односи на све језичке нивое.

Лингвокултуролошки и професионално-терминолошки аспекти изучаваног језика омогућавају споразумевање у иностраној (руској) говорној средини не само у социокултуролошком, већ и у професионално-терминолошком смислу, што омогућава језичку, интеркултурну и професионалну комуникацију. У оквиру војне струке она има следеће најважније функције: решавање професионалних задатака, организовање односа надређеног према подређенима, „служи и као средство за преношење информација, као средство за педагошки утицај” (Акинтьева 2007: 136).

Овладавање терминологијом војне струке матерњег и страног језика од огромног је значаја не само за официре који су на служби у војној дипломатији, већ и за оне на другим задужењима: «Распространение терминологической лексики в речи людей за пределами ситуаций общения, связанных с профессиональной деятельностью, является своеобразной приметой нашего времени» (Дегтяренко 2017: 34). ${ }^{3}$ Посао изасланика одбране подразумева у првом реду контакте са представницима оружаних снага земље пријема: „То је aktivnost koja se svakodnevno ispoljava, a počinje od kontakta sa zvaničnim predstavnicima oružanih snaga zemlje domaćina, u oficijalnim susretima, prisustvovanjem na prijemima, svečanostima, raznim proslavama, paradama i drugim prigodama koje domaćin orga-

\footnotetext{
3 „Ширење терминолошке лексике у говору људи изван оквира комуникативних ситуација које су повезане са професионалном делатношћу својеврсно је обележје нашег времена"(Дегтяренко 2017: 34).
} 
nizuje za vojno-diplomatski kor" (Zečević 1990: 73). Пре свега треба имати у виду приоритете у билатералној сарадњи (у конкретном периоду, односно друштвено-политичком тренутку), што свакако утиче на избор одређених лексичких јединица из терминолошког система војне струке. Несумњиво је неопходно познавање терминологије из војно-политичке, друштвено-политичке, друштвено-економске и војно-дипломатске сфере, на руском и српском језику. Ако бисмо узели у обзир савремени тренутак, он налаже и познавање терминологије из области међународне војне сарадње, као и војнотехничке сарадње, са нешто фреквентнијом употребом термина из области ваздухопловства и КоВ.

Службена задужења изасланика одбране могу га довести у ситуацију да наступа у улози преводиоца приликом званичних разговора, као и у неформалној комуникацији на војним дипломатским пријемима, што захтева високи степен познавања страног језика. У оваквим ситуацијама долазе до изражаја лингвокултуролошка знања и познавање војне струке, нпр. познавање руских скраћеница, као и релевантних чињеница које се односе на бивши СССР, познавање термина који су у недостатку адекватних еквивалената тешко преводиви на српски језик (за руски термин силовики не постоји монолексемни еквивалент, већ се мора преводити описно: униформисане структуре, или структуре силе, што се првенствено односи на Оружане снаге РФ, припаднике Министарства унутрашњих послова и Министарства за ванредне ситуације - МЧС). Са друге стране, познавање граматичких и правописних правила потребно је за писану комуникацију, као што су дипломатске ноте и сл.

Такође, треба скренути пажњу на велики број телефонских разговора које изасланик одбране обавља по службеној дужности, што подразумева фокусирање на аудитивни аспект страног језика, јер искључује визуелни контакт, који олакшава разумевање помоћу гестова и мимике. Због тога телефонска комуникција захтева одлично познавање страног језика.

Пошто преко 60\% војног дипломатског кора (ВДК) на руском говорном подручју у већој или мањој мери влада руским језиком, потреба за другим (енглеским) језиком није примарна, али је пожељна најчешће на нивоу A1/A2, посебно кад је реч о представницима ВДК чије је знање руског језика на нижем ступњу. Потребна знања енглеског језика у овом контексту своде се на познавање најосновнијих термина из области говорне етикеције (нпр. обраћање по чину), знање енглеских назива (или скраћаница) значајних институција и организација у Европи и свету, као и основних термина из војне струке, посебно у вези са неким врстама наоружања.

Треба напоменути да се проширивање лексичког фонда касније одвија и усавршава у аутентичној говорној средини, као и кроз комуникацију са припадницима војних изасланстава других држава у војном дипломатском кору.

Познавање страног језика потребно је и корисно за професију официра, јер подразумева не само способност комуникације на потребном језичком нивоу, већ и лакше успостављање међукултурног дијалога. Усвајање страног језика увек је повезано са откривањем нових видика и интеграцијом у мултикултуралну и мултијезичку реалност. Стога можемо закључити да потребна знања изасланика одбране, поред знања руског језика на нивоу В2/C1 (говорна, комуника- 
тивна, терминолошка и преводилачка компетенција), подразумевају и усвајање лингвокултуролошког аспекта у процесу учења страних језика, што је од специфичног значаја, посебно у превазилажењу евентуалних проблема на комуникативном нивоу.

\section{Цитирана литература}

Акинтьева, Виктория Е. «Особенности коммуникативной культуры военного специалиста». Вестник Ставропольского государственного университета 52, 2007 : $136-140$.

[Akint'eva, Viktoriiā E. «Osobennosti kommunikativnoù kul'tury voennogo spetsialista». Vestnik Stavropol'skogo gosudarstvennogo universiteta 52, 2007: 136-140]

Дегтяренко, Ксения А. «Структурно-семантические особенности и способы перевода терминологической лексики военного дискурса (на материале англоязычных периодических изданий)». Научный диалог 5, 2017: 33-43.

[Degtiārenko, Kseniiā A. «Strukturno-semanticheskie osobennosti i sposoby perevoda terminologicheskoî leksiki voennogo diskursa (na materiale angloiâzychnykh periodicheskikh izdaniǐ)». Nauchnyı̌ dialog 5, 2017: 33-43]

Кончаревић, Ксенија. Савремена настава руског језика: садржаји, организација, облици. Београд: Славистичко друшво Србије, 2004.

[Končarević, Ksenija. Savremena nastava ruskog jezika: sadržaji, organizacija, oblici. Beograd: Slavističko društvo Srbije, 2004]

Кончаревић, Ксенија. „Комуникативна личност српског парохијског свештеника: методолошке схеме и резултати параметарског истраживања". Црквене студије 7, 2010: 267-283.

[Končarević, Ksenija. „Komunikativna ličnost srpskog parohijskog sveštenika: metodološke sheme i rezultati parametarskog istraživanja". Crkvene studije 7, 2010: 267-283]

Пассов, Ефим И. Основы коммуникативной методики обучения иноязычному общению. Москва: Русский язык, 1989.

[Passov, Efim I. Osnovy kommunikativnoj metodiki obučeniâ inoâzyčnomu obŝeniû. Moskva: Russkij âzyk, 1989]

Сорокина, Эльвира А. «Язык для специальных целей как средство общения». Вестник Челябинского государственного университета 4, 2016: 169-172.

[Sorokina, Èl'vira A. «Ầzyk dlâ special'nyh celej kak sredstvo obŝeniâ». Vestnik Čelâbinskogo gosudarstvennogo universiteta 4, 2016: 169-172]

Стернин, Иосиф А. (ред.) Профессиональная коммуникативная личность. Воронеж: Истоки, 2007.

[Sternin, Iosif A. (red.) Professional'naiā kommunikativnaiā lichnost'. Voronezh: Istoki, 2007]

Bugarski, Ranko. Uvod u opštu lingvistiku. Beograd: Čigoja Štampa, 2003.

Zečević, Milan. Vojna diplomatija. Beograd: Vojnoizdavački i novinski centar, 1990. 
Драгана Радойчич

\title{
ЛИНГВИСТИЧКИЕ И ЛИНГВОКУЛЬТУРОЛОГИЧЕСКИЕ КОМПЕТЕНЦИИ ВОЕННЫХ АТТАШЕ В РУСОФОННОЙ СРЕДЕ
}

\begin{abstract}
Резюме
Коммуникативная, лингвистическая и культурная компетенции являются важными составляющими образовательной цели обучения иностранному языку, включающей в себя способность языковой реализации в разговорной речи, соответствующий уровень общения, а также овладение языковыми знаниями в связи с культурными и духовными особенностями социокультурной среды в определённой языковой сфере. Когда речь идёт об уровне владения иностранным языком офицеров, находящихся на должности военного атташе, или его заместителя, следует также обратить внимание на компетенцию, связанную со знанием военной терминологии. Элементы невербального общения также способствуют изучению моделей и стандартов поведения в повседневных ситуациях, а также межкультурному общению.

Владение иностранным (русским) языком военного атташе в русскоязычной среде также предполагает и высокий уровень владения языком военной профессии, что даёт возможность качественного профессионального общения.

Под лингвистической компетенцией в нашей работе мы понимаем речевую, коммуникативную, терминологическую и переводческую компетенции военных атташе. Выбор дидактического языкового материала должен соответствовать цели обучения, т.е. усваиванию указанных знаний и умений.

Параллельно с высоким уровнем владения языком принимающей страны (на всех языковых уровнях), желательно владеть английским языком на уровне элементарного общения, а также основными терминами из профессиональной сферы на этом языке.

Ключевые слова: военный атташе, иностранный (русский) язык, культура, языковая компетенция, лингвокультурологическая (культуроведческая) компетенция, социокультурная среда, экстралингвистические элементы, терминология, язык военной профессии.
\end{abstract}

